\title{
Cerebral venous thrombosis in ulcerative colitis and review of the literature
}

\author{
Hugh Chaun, BM, FRCP, FRCPC, JeFF H BECKMAN, MD, FRCPC, TERENCE G SPARLing, MD, FRCPC
}

H CHAUN, JH BECKMAN, TG SPARLING. Cerebral venous thrombosis in ulcerative colitis and review of the literature. Can J Gastroenterol 1991;5(4): 129-132. A 30-year-old man with an eight year history of ulcerative colitis developed left occipital headache, mental confusion, dysphasia and right-sided weakness when his bowel disease was asymptomatic. Investigations revealed thrombosis of the cerebral sagittal sinus and left transverse sinus. The literature relating to cerebrovascular complications associated with ulcerative colitis is reviewed, and the possible pathogenetic mechanisms of venous thrombosis in ulcerative colitis are discussed. The importance of recognizing that venous thrombosis may occur in association with ulcerative colitis in remission is emphasized.

Key Words: Cerebral venous thrombosis, Remission phase, Ulcerative colitis, Vascular complications

\section{Thrombose veineuse cérébrale et colite ulcéreuse - Observation et tour d'horizon de la littérature}

RESUME: Céphalée occipitale, confusion mentale, dysphasie et affaiblissement du côté droit ont été notés chez un patient âgé de 30 ans et atteint depuis huit ans d'une colite ulcéreuse alors asymptomatique. Les examens ont révélé une thrombose du sinus sagittal et du sinus latéral gauche. Les auteurs effectuent un tour d'horizon de la littérature traitant des complications cérébrovasculaires associées à la colite ulcéreuse. Ils examinent les mécanismes pathogéniques possibles de la thrombose veineuse dans ces circonstances et soulignent qu'il est important de reconnaître qu'elle peut survenir chez la personne atteinte d'une colite ulcéreuse en rémission.

Divisions of Gastroenterology, Neurology and Hematology, Department of Medicine, University Hospital; and University of British Columbia, Vancouver, British Columbia

Correspondence and reprints: Dr Hugh Chaun, Suite 601, 805 West Broadway, Vancouver, British Columbia V5Z IK1. Telephone (604) 872-0717

Received for publication April 25, 1991. Accepted June 3, 1991
$\mathrm{T}$ HE ASSOCIATION OF VASCULAR lesions with idiopathic inflammatory bowel disease (IBD) is well recognized (1). Vascular complications associated with ulcerative colitis include venous thrombosis (2-4), arterial thrombosis $(2,5)$, Takayasu's disease (6), ischemic skin lesions (7), and vasculitis $(8,9)$. Bargen and Barker in 1936 (2) first drew attention to the serious implications of thromboembolism complicating ulcerative colitis. Since Harrison and Truelove (10) first reported cerebral venous thrombosis in two ulcerative colitis patients, there have been other well documented reports of the association of cerebrovascular disease with ulcerative colitis; the majority have occurred with active bowel disease. This report describes a patient with ulcerative colitis in remission who developed cerebral sagittal sinus and left transverse sinus thrombosis.

\section{CASE PRESENTATION}

A 30-year-old accountant, a nonsmoker, was transferred from another hospital on December 6, 1990 for evaluation of cerebral hemorrhagic infarction. The patient had a history of ulcerative colitis since 1982, when he 


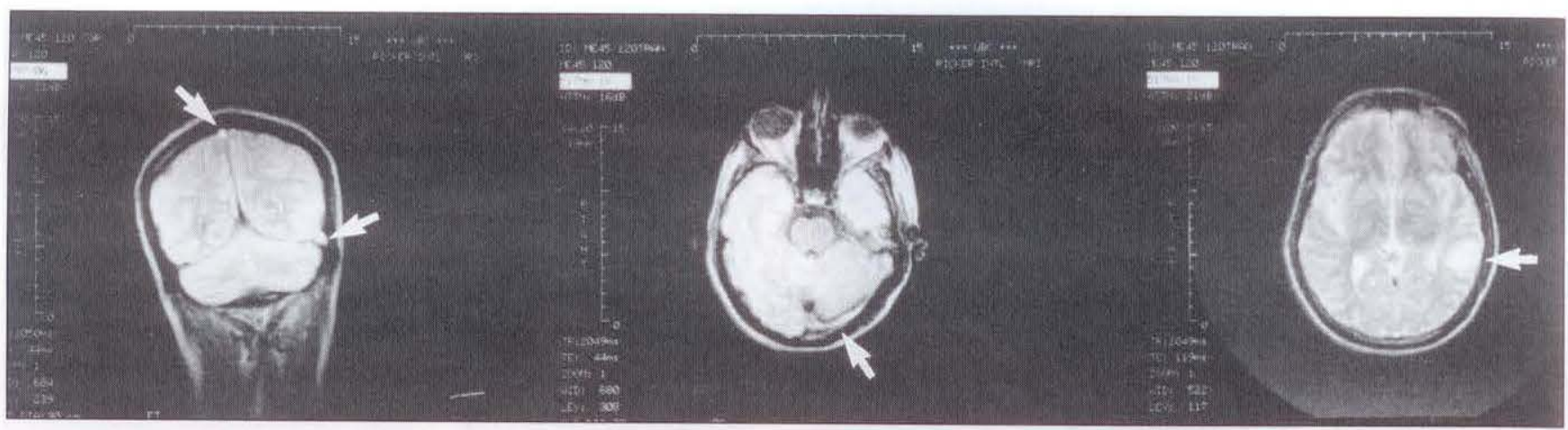

Figure 1) Left Magnetic resonance imaging (MRI) scan showing increased signal of superior sagittal sinus and sigmoid sinus indicative of venous thrombosis. Centre MRI scan showing transverse sinus thrombosis. Right MRI scan showing left parietal venous infarction

had presented with severe diarrhea with bleeding, weight loss and anemia. He was treated in hospital with blood transfusion, sulphasalazine and intravenous hydrocortisone, followed by prednisone for two months. The patient continued to take sulphasalazine until December 1988, and had occasional abdominal cramps and rectal bleeding. In mid-October 1990, he developed an acute exacerbation of the ulcerative colitis which responded rapidly to treatment with prednisone and sulplasalazine in hospital, and he became asymptomatic.

While at work on November 13, the patient complained of left occipital headache and vomited. He was confused, had difficulty finding words, and had weakness of the right arm and leg. He had no fever or prodromal illness (including otitis and mastoiditis), no history of rheumatic heart disease, recent dental or surgical procedure, intravenous drug abuse or homosexual contact, and no family history of neurological or collagen vascular disease. He had no heart murmur or carotid bruit.

Cerebrospinal fluid analysis showed protein $0.51 \mathrm{~g} / \mathrm{L}$ (normal 0.15 to 0.4 ), glucose $4.0 \mathrm{mmol} / \mathrm{L}$, white blood cells $1 / \mathrm{mm}^{3}$, red blood cells $560 / \mathrm{mm}^{3}$. Computed tomography (CT) scan showed three hemorrhagic infarcts in the left hemisphere, one in the temporal area and two in the deep white matter. Blood cultures were negative but the patient was treated empirically with broad spectrum antibiotics. He was started on phenytoin for seizure pro- phylaxis, and dexamethasone. The headache and mental confusion resolv ed, and speech and strength in the right limbs improved, showing only mild impairment of fine finger movements of the right hand.

Magnetic resonance imaging (MRI) scan revealed evidence of sagittal sinus and left transverse sinus thrombosis (Figure 1). Cerebral angiogram confirmed almost total thrombosis of the sagittal sinus and partial thrombosis of the left transverse sinus (Figure 2). Complete blood count (including platelets), erythrocyte sedimentation rate, prothrombin time, activated partial thromboplastin time, the $\mathrm{C} 3$ and C4 components of complement, protein $\mathrm{C}$, plasminogen, alpha- 2 antiplas$\mathrm{min}$, and relative serum viscosity at $20^{\circ} \mathrm{C}$ and $37^{\circ} \mathrm{C}$ were normal. Antithrombin III was 2.10 (normal 0.91 to 1.38 ) and protein $\mathrm{S}$ was 1.40 (normal 0.57 to 1.20 ). A lupus anticoagulant was excluded by a normal dilute Russell viper venom time and a normal tissue thromboplastin inhibition test. Sugar water test and rheumatoid factor were negative. The antinuclear factor was slightly positive with a titre of $1: 80$. Serum protein was $62 \mathrm{~g} / \mathrm{L}$ (normal 63 to 82). Protein electrophoresis showed albumin $36.3 \mathrm{~g} / \mathrm{L}$ (normal 37 to 50 ), alpha-1-globulin $3.4 \mathrm{~g} / \mathrm{L}$ (normal 1.5 to 3.2), and normal alpha-2-globulin, beta-globulin and gamma-globulin. Other biochemical tests including blood glucose, cholesterol and trigly. ceride were normal. Serology test for human immunodeficiency virus was negative. Plasma reagin test and hepatitis B surface antigen were nonreactive. Electrocardiogram, echocardiography and colour flow duplex ultrasound of both lower limbs and pelvic veins were normal. CT scan and $x$-rays of the mastoid and paranasal sinuses showed no significant abnormality. Sigmoidoscopy showed normal mucosa.

Treatment with dexamethasone was changed to prednisone on tapering doses, finally discontinued on December 31 . The patient was discharged on December 19 , on warfarin and 5 . aminosalicylic acid, and has remained well.

\section{DISCUSSION}

Thromboembolic complications have been known to be a significant cause of morbidity and mortality in patients with IBD since their recognition in 1936 (2). The reported incidence of thrombosis has ranged between 1.3 and $6.4 \%$ during life $(3,11)$, with a $25 \%$ mortality rate (11) to $39 \%$ at post mortem (4). In the Mayo Clinic series, 61 of 92 patients had deep venous thrombosis or pulmonary emboli, and only nine patients had cerebrovascular episodes (11).

Review of the English language literature disclosed references to 22 patients with adequately documented descriptions of cerebrovascular complications which developed in association with ulcerative colitis $(10-23)$. The male to female ratio was $11: 10$; the sex of one patient was not identified. The patients ranged in age from five to 54 years (mean 28.3). The presenting fea- 

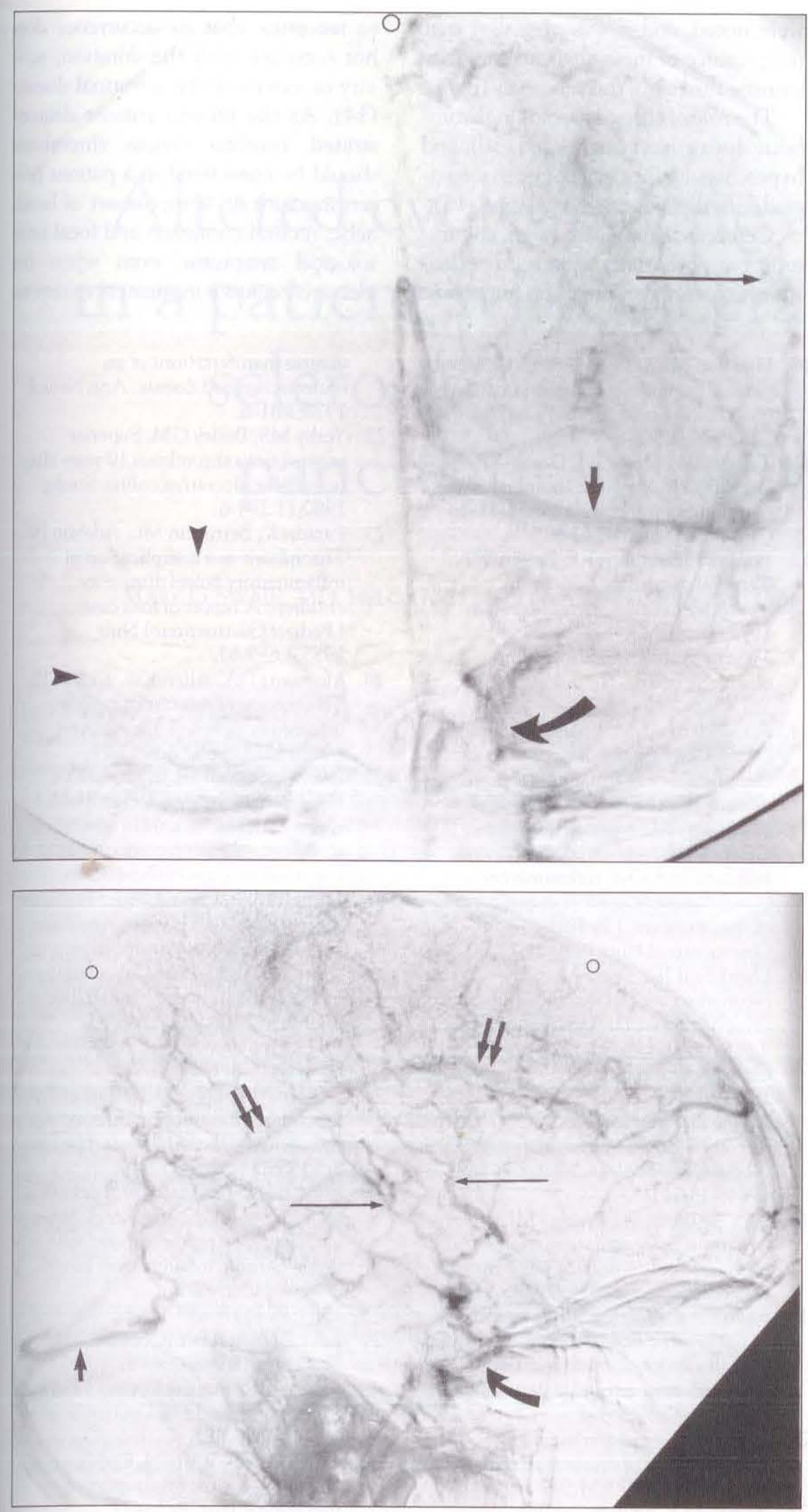

Figure 2) Anteroposterior (top) and lateral (bottom) views of the venous phase of the left internal carotid angiogram show failure to opacify the superior sagittal sinus (o). There is only partial opacification of the left transverse sinus (short arrows) and no opacification of the left sigmoid sinus or internal jugular vein. Faint filling of the right transverse and sigmoid sinuses is seen (arrowheads). The inferior sagittal sinus (paired arrows) is slightly enlarged and multiple small tortuous cortical veins (long arrows) provide collateral drainage to the left cavernous sinus (curved arrows) tures included headache, loss of vision, aphasia, hemiparesis, seizures, mental confusion and stupor. The cerebrovascular lesions were diagnosed clinically in 12 patients (with only limited data in four). The diagnosis was confirmed by angiography in six patients (two also at autopsy), at operation in one, at autopsy in one, and by CT scan in two, one of whom also underwent MRI. The cerebrovascular events occurred during the acute phase of ulcerative colitis in all but seven patients. The disease was in remission in one patient, controlled in two and unknown in one. Three patients had had proctocolectomy one developed superior sagittal venous sinus thrombosis 10 years after the operation. Nine of the 22 patients also had a history of extracerebral thromboembolic disease.

Although most patients had active bowel disease at the time of thrombosis (11), the patient in the present report developed the complication when his ulcerative colitis had returned to a remission phase. He had no other apparent risk factor for thromboembolic disease or hypercoagulable state. The role of anticoagulant therapy in cerebral venous thrombosis is controversial $(10,14,21)$, but the decision to use it in this patient was made easier as his colonic disease was asymptomatic.

The pathogenesis of venous thrombosis in ulcerative colitis remains obscure. Hypercoagulability associated with thrombocytosis $(18,24)$, elevated fibrinogen $(11,18,25)$, elevated factors $\mathrm{V}$ and VIII $(11,18,25)$, decreased antithrombin III $(18,24)$ and accelerated thromboplastin generation (26) have been postulated as possible causative mechanisms. However, most patients were evaluated when their bowel disease was active and these abnormalities in coagulation, which occur in active IBD, have not been proven to be causative factors in venous or arterial thromboembolic disease (27). When patients were studied during a quiescent phase of their disease, no significant prethrombotic abnormalities were found $(28,29)$. With two exceptions $(24,27)$, previous studies did not assess the newly recognized thrombotic disorders involving deficiency of protein $\mathrm{C}$ 
or protein $\mathrm{S}$, the vitamin $\mathrm{K}$-dependent natural anticoagulants. No deficiency was demonstrated in the present patient. In a study of IBD patients with little or no disease activity (27), all standard coagulation tests as well as protein $\mathrm{C}$ and protein $\mathrm{S}$ were normal. However, a high incidence of abnormalities in fibrinolysis and elevated levels of circulating immune complexes

ACKNOWLEDGEMENTS: The authors thank Dr Douglas A Graeb, Head, Division of Neuroradiology, Vancouver General Hospital, for his invaluable help with the photographs of the cerebral angiogram, and Dr Robert R Love for his referral and update of the patient.

\section{REFERENCES}

1. Sidorov JJ. Extraintestinal manifestations of inflammatory bowel disease. In: Freeman HJ, ed. Inflammatory Bowel Disease, vol II. Boca Raton: CRC Press Inc, 1989:51-74.

2. Bargen JA, Barker NW. Extensive arterial and venous thrombosis complicating chronic ulcerative colitis. Arch Intern Med 1936;58:17-31.

3. Edward, FC, Truelove SC. The course and prognosis of ulcerative colitis. III. Complications. Gut 1964;5:1-22.

4. Graef V, Baggenstoss AH, Sauer WG, Spittell JA Jr. Venous thrombosis occurring in nonspecific ulcerative colitis. A necropsy study. Arch Intern Med 1966;117:377-82.

5. Braverman D, Bogoch A. Arterial thrombosis in ulcerative colitis. Am J Dig Dis 1978;23:1148-52.

6. Chapman R, Dawe C, Whorwell PJ, Wright R. Ulcerative colitis in association with Takayasu's disease. Am J Dig Dis 1978;23:660-2.

7. Chaun H, Day J, Dodd WA, Dunn WL. Ischemic skin lesions in ulcerative colitis. Can Med Assoc J 1985;132:937-9.

8. McDermott V, McCarthy CF. A case of ulcerative colitis presenting as vasculitic purpura. Dig Dis Sci 1985;30:495-6.

9. Newton JA, McGibbon DH, Marsden RA. Leucocytoclastic vasculitis and angiooedema associated with inflammatory bowel disease. Clin Exp Dermatol 1984;9:618-23. were noted, and it was suggested that the presence of these abnormalities may increase the risk of thrombosis in IBD.

The role of corticosteroids in thrombotic disease has been refuted (30), and hypercoagulability has not been associated with the use of sulphasalazine (15).

Cerebral thrombosis is an uncommon but potentially serious complication of ulcerative colitis. It is important

10. Harrison MJG, Truelove SC. Cerebral venous thrombosis as a complication of ulcerative colitis. Am J Dig Dis 1967;12:1025-8.

11. Talbot RW, Heppell J, Dozois RR, Beart RW Jr. Vascular complications of inflammatory bowel disease. Mayo Clin Proc 1986;61:140-5.

12. Borda IT, Southern RF, Brown WF. Cerebral venous thrombosis in ulcerative colitis. Gastroenterology 1973;64:116-9.

13. Mayeux R, Fahn S. Strokes and ulcerative colitis. Neurology 1978;28:571-4.

14. Schneiderman JH, Sharpe JA, Sutton DMC. Cerebral and retinal vascular complications of inflammatory bowel disease. Ann Neurol 1979;5:331-7.

15. Markowitz RL, Ment LR, Gryboski JD. Cerebral thromboembolic disease in pediatric and adult inflammatory bowel disease: Case report and review of the literature. J Pediatr Gastroenterol Nutr 1989;8:413-20.

16. Lloyd-Still JD, Tomasi L. Neurovascular and thromboembolic complications of inflammatory bowel disease in childhood. J Pediatr Gastroenterol Nutr 1989;9:110-5.

17. Kehoe EL, Newcomer KL. Thromboembolic phenomena in ulcerative colitis. Arch Intern Med 1964;113:711-5.

18. Lam A, Borda IT, Inwood MJ, Thomson S. Coagulation studies in ulcerative colitis and Crohn's disease. Gastroenterology 1975;68:245-51.

19. Ryan FP, Timperley WR, Preston FE, Holdsworth CD. Cerebral involvement with disseminated intravascular coagulation in intestinal disease. J Clin Pathol 1977;30:551-5

20. Edwards KR. Hemorrhagic complications of cerebral arteritis. Arch Neurol 1977;34:549-52.

21. Averback P. Primary cerebral venous thrombosis in young adults: The to recognize that its occurrence does not correlate with the duration, activity or extent of the intestinal disease (14). As the present patient demonstrated, cerebral venous thrombosis should be considered in a patient presenting with an abrupt onset of head ache, mental confusion and focal neu rological symptoms, even when the ulcerative colitis is in apparent remission.

diverse manifestations of an underrecognized disease. Ann Neurol 1978:3:81-6.

22. Yerby MS, Bailey GM. Superior sagittal sinus thrombosis 10 years after surgery for ulcerative colitis. Stroke 1980;11:294-6.

23. Paradis K, Bernstein ML, Adelson JW. Thrombosis as a complication of inflammatory bowel disease in children: A report of four cases. J Pediatr Gastroenterol Nutr 1985;4:659-62.

24. Morowitz DA, Allen LW, Kirsner JB. Thrombocytosis in chronic inflammatory bowel disease. Ann Intern Med 1968;68:1013-21.

25. Lee LC, Spittell JA Jr, Sauer WG. Hypercoagulability associated with chronic ulcerative colitis: Changes in blood coagulation factors. Gastroenterology 1968;54:76-85.

26. Spittell JA Jr, Owen CA Jr, Thompson JH Jr, Sauer WG. Hypercoagulability and thrombosis in chronic ulcerative colitis. In: 1963-1964 Collected Papers in Medicine from the Mayo Clinic and the Mayo Foundation, vol 53. Philadelphia and London: WB Saunders Co, 1963:53-7.

27. Conlan MG, Haire WD, Burnett DA. Prothrombotic abnormalities in inflammatory bowel disease. Dig Dis Sci 1989;34:1089-93.

28. Knot EAR, Ten Cate JW, Leeksma $\mathrm{OCH}$, Tytgat GN, Vreeken J. No evidence for a prethrombotic state in stable chronic inflammatory bowel disease. J Clin Pathol 1983;36:1387-90.

29. Lake AM, Stauffer JQ, Stuart MJ. Hemostatic alterations in inflammatory bowel disease. Response to therapy. Am J Dig Dis 1978;23:897-902

30. Truelove SC, Witts LJ. Cortisone in ulcerative colitis; final report on therapeutic trial. Br Med J $1955 ; 2: 1041-8$. 


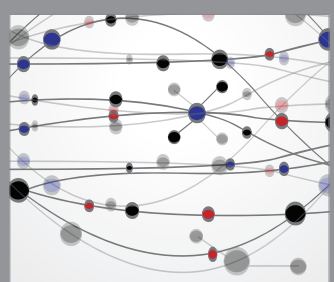

The Scientific World Journal
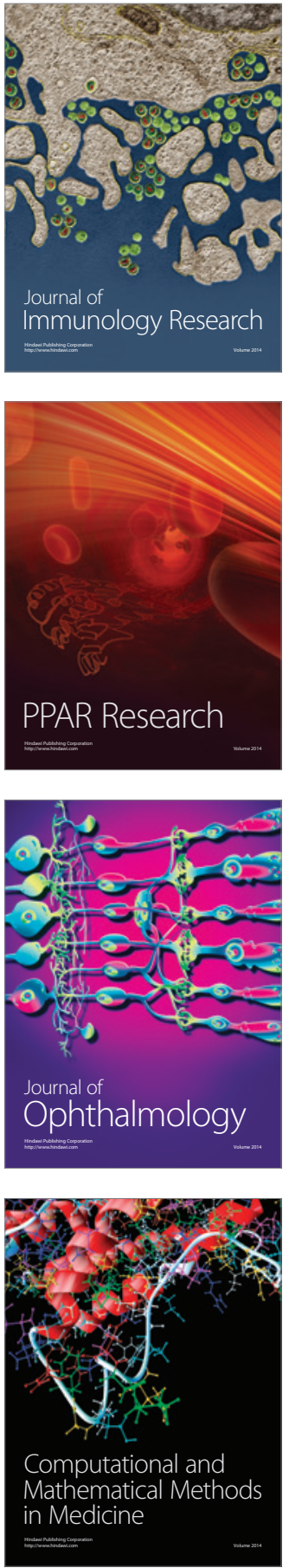

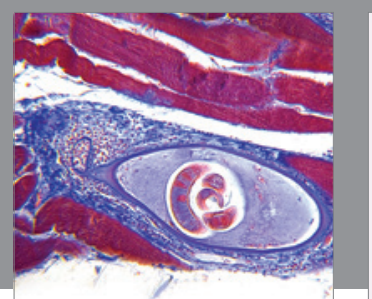

Gastroenterology Research and Practice

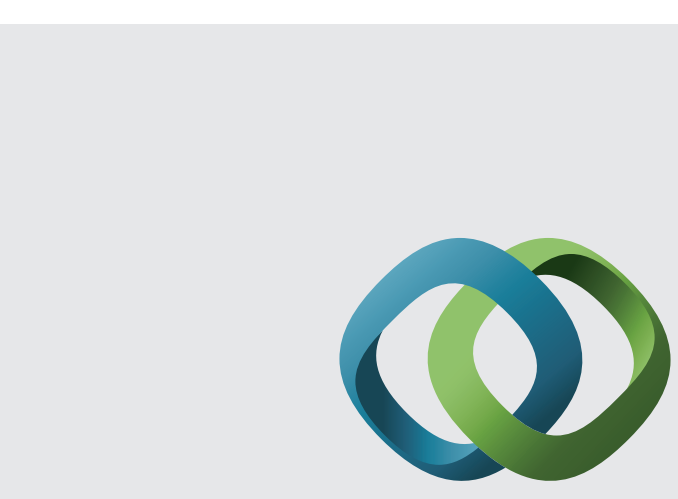

\section{Hindawi}

Submit your manuscripts at

http://www.hindawi.com
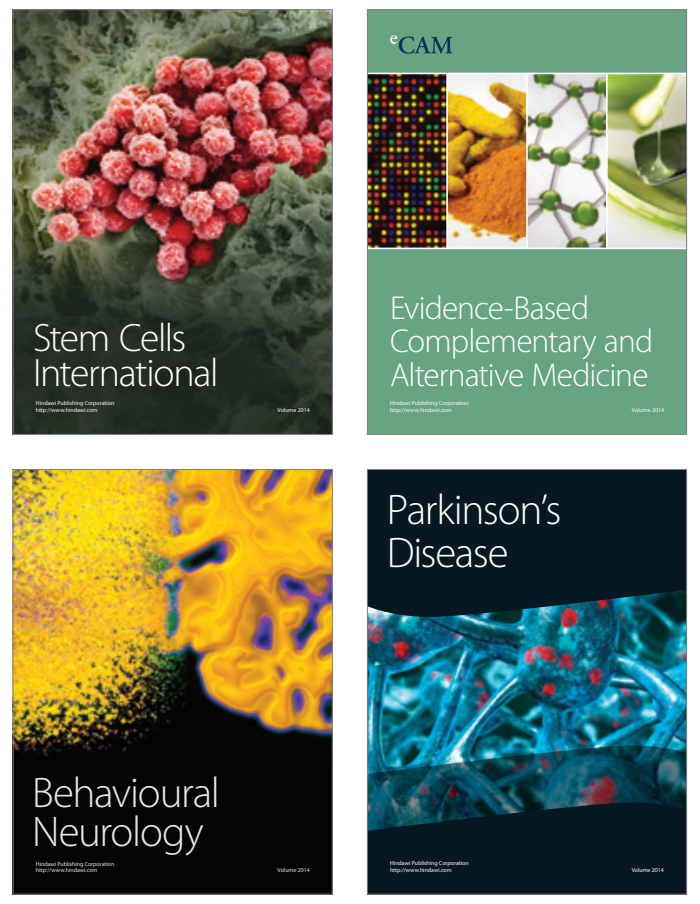
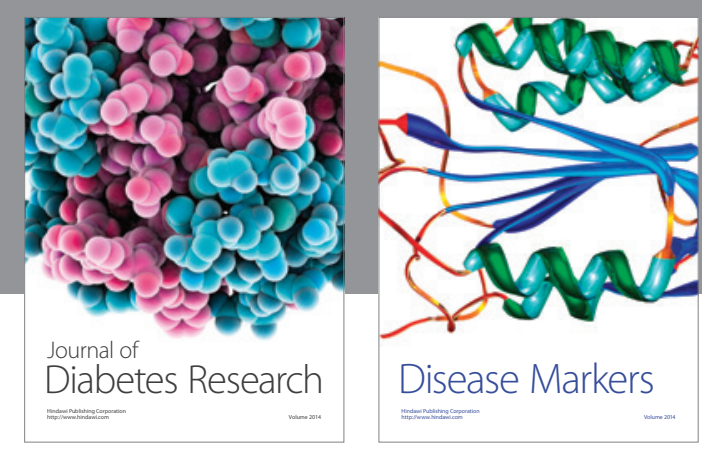

Disease Markers
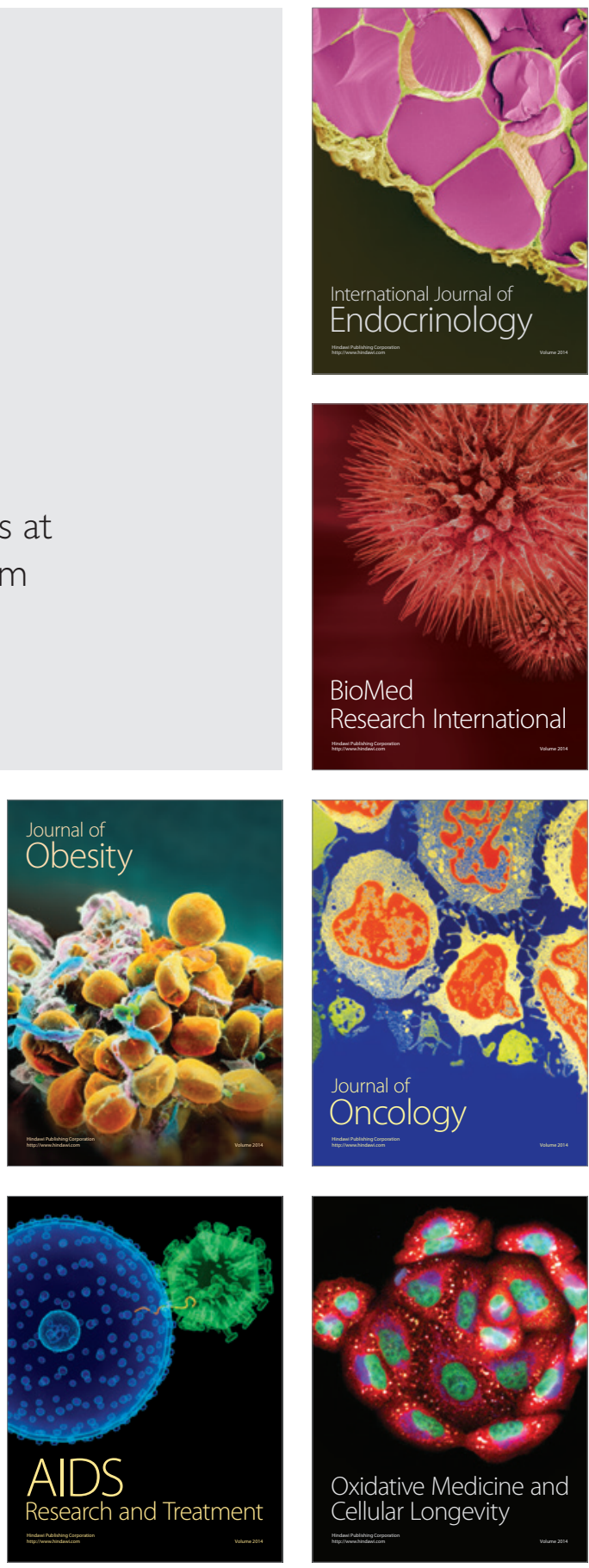